EWA ZENDER-ŚWIERCZ1

OLGA JĘDRZEJCZYK

KAROLINA KACZOROWSKA

Kielce University of Technology

'e-mail: ezender@tu.kielce.pl
Manuscript submitted 2017.07.11 - revised 2017.09.29, initially accepted for publication 2018.01.02, published in March 2018

\title{
THE ANALYSIS OF THERMAL COMFORT IN THE SCHOOL AND THE WEDDING HOUSE
}

\section{ANALIZA KOMFORTU CIEPLNEGO W SZKOLE I DOMU WESELNYM}

DOI: $10.30540 /$ sae-2018-007

\begin{abstract}
A bstract
The environment, where people are staying, should provide thermal comfort. It means that the equilibrium of the amount of heat produced in the human body and the amount of heat lost to the environment should be kept. To achieve the suitable conditions of air there the air conditioning, ventilation and heating systems are used. These systems regulate the air parameters and maintain them at the desired level. Designers locate, most commonly, the supply units of air conditioning systems in the ceiling in the central part of the room or near the windows without taking into account the specificity of the premises. However, such an approach may contribute to the lack of thermal comfort. The sensation of air is a very subjective indicator that depends on many variables. The authors of the article made an attempt to analyze the influence of the type of air conditioning system and location of air supply units on the thermal comfort in rooms of different use.
\end{abstract}

Keywords: thermal comfort, air conditioning, simulation

\begin{abstract}
Streszczenie
Środowisko, w którym przebywa człowiek powinno zapewniać odczuwanie komfortu. tzn. powinna być zachowana równowaga pomiędzy ilościa ciepła wytwarzanego w ciele człowieka a ilościa ciepła traconego do otoczenia. Aby uzyskać taki stan powietrza w pomieszczeniach, stosuje się różne systemy wentylacji, klimatyzacji i ogrzewania. Układy te reguluja parametry powietrza i utrzymuja je na żadanym poziomie. Projektanci lokalizuja elementy nawiewne instalacji klimatyzacji najczęściej w suficie w centralnej części pomieszczenia lub przy oknach bez uwzględniania specyfiki pomieszczenia. Jednak takie spojrzenie na instalację może przyczynić się do braku warunków komfortu cieplnego. Postrzeganie stanu powietrza jest bardzo subiektywnym wskaźnikiem zależnym od wielu zmiennych. W artykule podjęto próbę analizy wptywu rodzaju instalacji klimatyzacji oraz rozmieszczenia elementów nawiewnych w pomieszczeniach o różnym przeznaczeniu.
\end{abstract}

Slowa kluczowe: komfort termiczny, klimatyzacja, symulacje

\section{Introduction}

The internal environment is the subject of interest to many scientists. This is the result from essential influence of internal parameters on the health of the occupants. The inappropriate temperature, humidity or air composition can cause a sick building syndrome. Even without the visible deterioration of human health, we can see the impact of the inappropriate micro-environment on decrease productivity, learning performance or disorders of sleep or emotions. The air parameters are also important for the structure of the building as shown in [1]. In the literature [2] there

\section{Wstęp}

Środowisko wewnętrzne jest przedmiotem zainteresowań wielu naukowców. Wynika to z istotnego wpływu parametrów wewnętrznych na stan zdrowia osób przebywających w pomieszczeniach. Niewłaściwy układ temperatury, wilgotności oraz skład powietrza może powodować syndrom chorego budynku. Nawet bez widocznego pogorszenia stanu zdrowia wpływ mikrośrodowiska ukazuje się w spadku wydajności pracy, uczenia się lub kłopotów ze snem czy też zaburzeń stanów emocjonalnych. Parametry powietrza są istotne również dla konstrukcji budynku co pokazano w [1]. 
was shown how important the indoor air quality is, there the scientists have shown the influence of air quality on people's sensations. There the influence of temperature, air velocity and location of supply elements depending on the type of air conditioning system and the use of the buildings were analyzed in the article.

\section{Subject of study}

Two public buildings were analyzed: a school and a wedding house with hotel's rooms. Two alternative air conditioning systems were designed in those buildings. One of them was a centralized system equipped with zone heaters to prepare parameters for the whole zone according to its requirements. The second system was equipped with wall's air conditioners located in each of the rooms. In the first solution, it was not possible to individually adjust the parameters for each room, but for the whole zone. In the second solution, the users were able to adjust the parameters individually. The simulation of parameters of supply air was done in lindQST LINDAB. The premises of each category were selected for analysis. The classroom and teacher's room were chosen in the school building. The wedding hall and the hotel room were chosen in the wedding house. Table 1 presents the data of each analyzed room. The internal air parameters were chosen according to standard [3].

Table 1. The data of the analyzed rooms
Jak bardzo istotnym jest stan powietrza wewnętrznego pokazuje literatura [2], gdzie naukowcy ukazali wpływ jakości powietrza na osoby przebywające w pomieszczeniu. $\mathrm{W}$ artykule przeanalizowano wpływ temperatury, prędkości powietrza oraz lokalizacji elementów nawiewnych w zależności od rodzaju instalacji klimatyzacji oraz od przeznaczenia budynków.

\section{Przedmiot analizy}

Analizie poddano dwa budynki użyteczności publicznej: szkołę oraz dom weselny z pokojami hotelowymi. W obiektach zaprojektowano dwa alternatywne systemy klimatyzacji. Jeden stanowił scentralizowany układ wyposażony w nagrzewnice strefowe przygotowujące parametry dla całej strefy w zależności od wymagań im postawionych. Drugi system wyposażony był w klimatyzatory ścienne zlokalizowane w każdym z pomieszczeń. W pierwszym przypadku nie było możliwości indywidualnej regulacji parametrów dla każdego pomieszczenia, ale dla całej strefy, w drugim przypadku użytkownicy mają możliwość regulacji parametrów indywidualnie. Symulację parametrów powietrza nawiewanego wykonano w programie lindQST LINDAB. Do analizy wybrano pomieszczenia z każdej kategorii. W budynku szkoły była to: sala lekcyjna oraz pokój nauczycielski, w domu weselnym: sala weselna oraz pokój hotelowy. W tabeli 1 zaprezentowano dane dotyczące poszczególnych pomieszczeń poddanych analizie. Parametry powietrza wewnętrznego dobrano zgodnie z normą [3].

Tabela 1. Dane dotyczace analizowanych pomieszczeń

\begin{tabular}{|c|c|c|c|c|c|c|}
\hline The premises & Area $\left[\mathrm{m}^{2}\right]$ & Cubage $\left[\mathrm{m}^{3}\right]$ & Heat gains $[\mathrm{kW}]$ & Stream of supply air $\left[\mathrm{m}^{3} \mathrm{~h}^{-1}\right]$ & Internal temperature $\left.{ }^{\circ} \mathrm{C}\right]$ & Humidity $[\%]$ \\
\hline Classroom & 45.1 & 112.7 & 3.5 & 878 & 24 & 50 \\
\hline Teacher's room & 21.4 & 53.6 & 4.4 & 1090 & 24 & 50 \\
\hline Wedding hall & 212.4 & 894.6 & 16.09 & 9657 & 21 & 50 \\
\hline Hotel room & 27.2 & 84.3 & 0.58 & 180 & 23 & 50 \\
\hline
\end{tabular}

The value of the Predicted Mean Vote (PMV) along the room (with the interval of $1 \mathrm{~m}$ ) was calculated on the base of the parameters obtained in the simulation. Fanger's model was chosen to the analysis according to the standard [4]. This is a commonly used method for assessing the thermal comfort of premises. The researchers have shown that in hot and humid climate, this model is unsuitable because of too much variance in real and calculated values, which was shown in [5]. However, the location of the analyzed objects in
Na podstawie parametrów uzyskanych w symulacji obliczono wartość wskaźnika PMV na długości pomieszczenia z interwałem $1 \mathrm{~m}$. Do analizy wybrano model Fangera wg normy [4]. Jest to powszechnie stosowana metoda do oceny komfortu cieplnego pomieszczeń. Naukowcy wykazali, iż w klimacie gorącym i wilgotnym model ten nie sprawdza się z uwagi na zbyt duże odchylenia wartości uzyskanych w warunkach rzeczywistych i obliczonych, co pokazuje [5]. Jednak lokalizacja analizowanych obiektów 
moderate climate allows for successful application of the chosen model. At the same time, it should be noted that Aravind Kumar A. and others [6] have shown the influence of insulating materials on thermal comfort what are not included in the Fanger's model. The metabolism of people has the greatest influence on the value of PMV, what was shown in [7]. The conducted analysis includes metabolism depending on the activity of people.

\section{Analysis}

The thermal comfort analysis was conducted for the summer period. The external air parameters were assumed according to the standard [8]: temperature $30{ }^{\circ} \mathrm{C}$ and humidity $45 \%$. Two alternative air conditioning systems for each of the buildings were designed. The air flows were calculated and the components of the systems were selected. The simulation of flow of supply air was conducted in the lindQST LINDAB program (Fig. 1). On the base of the simulation's effects, the distribution of temperature and air velocity at the border of the people's residence zone (ie at the height of $1.8 \mathrm{~m}$ from the floor level) have been specified. w klimacie umiarkowanym pozwala $\mathrm{z}$ powodzeniem zastosować wybrany model. Jednocześnie nadmienić należy, iż Aravind Kumar A. i inni [6] wykazali wpływ na komfort termiczny materiałów izolacyjnych, które nie są uwzględnione w modelu Fangera.

Największy wpływ na wartość wskaźnika PMV ma metabolizm osób przebywających w pomieszczeniu, co pokazuje [7]. W artykule uwzględniono metabolizm w zależności od aktywności osób przebywających w poszczególnych pomieszczeniach.

\section{Analiza}

Analizę komfortu cieplnego wykonano dla okresu letniego. Założono parametry powietrza zewnętrznego zgodnie $\mathrm{z}$ normą [8]: temperatura $30^{\circ} \mathrm{C}$ oraz wilgotność $45 \%$. Wykonano po dwa alternatywne projekty instalacji klimatyzacji dla każdego z budynków. Obliczono strumień powietrza klimatyzacyjnego i dobrano elementy końcowe instalacji. $\mathrm{W}$ programie lindQST LINDAB wykonano symulację nawiewu powietrza (rys. 1). Na tej podstawie określono rozkład temperatury i prędkości powietrza na granicy strefy przebywania ludzi, tj. na wysokości $1,8 \mathrm{~m}$ od poziomu podłogi. a)

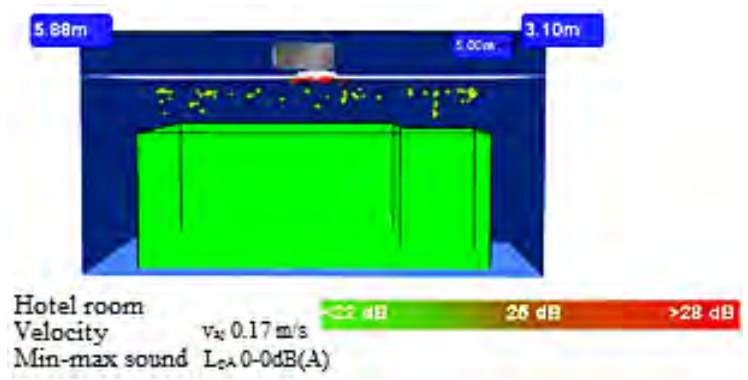

c)

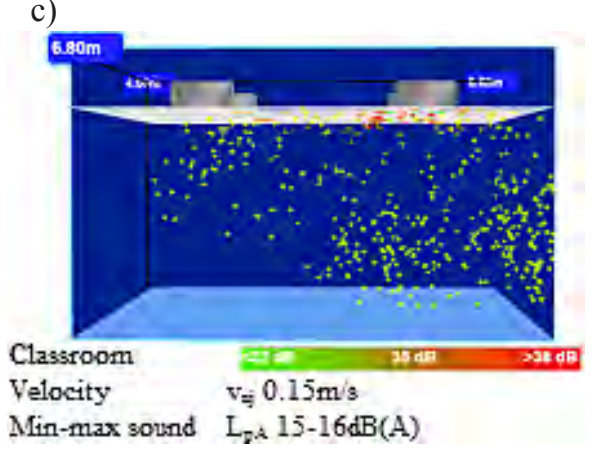

b)

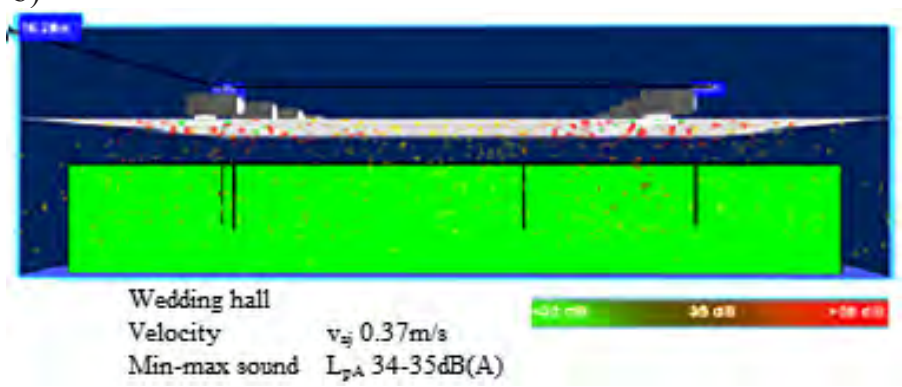

d)

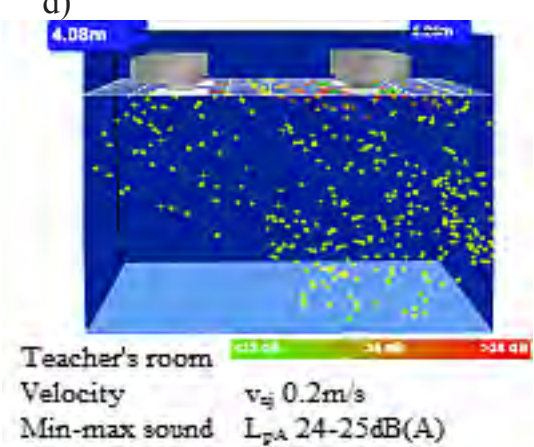

Fig. 1. The simulation of distribution of air velocity and air temperature - air conditioning system with zone heaters: a) hotel room, b) wedding hall, c) teacher's room, d) classroom

Rys. 1. Symulacja rozkładu prędkości i temperatury - system z nagrzewnicami strefowymi: a) pokój hotelowy, b) sala weselna, c) pokój nauczycielski, d) sala lekcyjna 
The results of the simulation allowed to calculate the value of the PMV coefficient. The values of the analyzed parameter were shown in the graph in Figure 2. Depending on the type of room, the supply air parameters created by the various air conditioning systems gave a different values of PMV.

The supply grate of the centralized air conditioning system was located in the center of the hotel room. The value of PMV was lower near the walls, and in the rest of the room's area the value was constant and equals 0.1 . In a system with a wall's air conditioners, the PMV value was decreasing as it moved away from the wall and from the center of the room the indicator's value was growing.

In the wedding hall, both the supply grates of the central air conditioning system and the wall's air conditioners were located on the opposite sides of the room along the walls. In the first solution near the supply grates, the PMV value was higher. In the central part of the wedding hall the PMV value was kept at a constant level, equal to the value obtained for the wall's air conditioners. In the system with wall's air conditioners the value was constant throughout the room.

In the classroom the supply grates of the central air conditioning system were located on both sides of the room and the thermal comfort factor was decreasing along the room. In the system with wall's air conditioners the PMV value was initially decreasing, and from the center of room was growing up.

In the teacher's room the location of the installation's elements was similar to the classroom. For this room, the value of the PMV was growing as the measurement was moving away from the wall's air conditioner. While, in the case of the central air conditioning system, the PMV value was decreasing along the room and from the center of room it was oscillating around the constant value.

Based on the analysis of the obtained data, it can be seen that both proposed solutions of the air conditioning systems are creating the microclimate parameters making comfortable conditions for the users. At the same time it cannot be said that one of the analyzed systems is better.

To the analyze the air conditioning system equipped with zone heaters the graph was created (Fig. 3). The most comfortable conditions were obtained in the hotel and teacher's room, it means in the rooms with the smallest number of people. The highest values of the PMV factor were obtained in the wedding hall, where the largest number of people is and the physical activity is highest.
Wyniki symulacji pozwoliły na obliczenie wartości wskaźnika komfortu cieplnego PMV. Wartości analizowanego parametru przedstawiono $\mathrm{w}$ formie wykresu na rysunku 2. W zależności od rodzaju pomieszczenia parametry powietrza nawiewanego kreowane przez różne systemy klimatyzacji dawały inną wartość wskaźnika PMV.

W pokoju hotelowym nawiewnik klimatyzacji centralnej zlokalizowany był $\mathrm{w}$ środku pomieszczenia. Wartość wskaźnika komfortu cieplnego była niższa $\mathrm{w}$ pobliżu ścian, a w pozostałej części pomieszczenia była stała i wynosiła 0,1 . W systemie $\mathrm{z}$ klimatyzatorem ściennym wartość wskaźnika malała w miarę oddalania się od ściany, a od środka pomieszczenia rosła.

Na sali weselnej zarówno nawiewniki systemu klimatyzacji centralnej, jak i klimatyzatory zlokalizowane były po obu stronach pomieszczenia wzdłuż ścian. W przypadku pierwszego rozwiązania w bliskiej odległości od nawiewników wartość wskaźnika PMV była wyższa. W centralnej części pomieszczenia utrzymywała się na stałym poziomie, równym wartości uzyskanej dla klimatyzatorów, dla których wartość była stała w całym pomieszczeniu.

W przypadku sali lekcyjnej nawiewniki klimatyzacji centralnej zlokalizowane były po obu stronach pomieszczenia, a wskaźnik komfortu cieplnego zmniejszał się wzdłuż pomieszczenia. W przypadku klimatyzatorów ściennych wskaźnik PMV początkowo malał, a od środka pomieszczenia zaczął wzrastać.

W pokoju nauczycielskim lokalizacja elementów instalacji była analogiczna do sali lekcyjnej. W tym przypadku wartość wskaźnika PMV wzrastała w miarę oddalania się od klimatyzatora ściennego, natomiast w przypadku klimatyzacji centralnej malała wzdłuż pomieszczenia, a od jego środka oscylowała wokół stałej wartości.

Na podstawie analizy uzyskanych danych można zauważyć, iż oba proponowane rozwiązania instalacji klimatyzacji regulują parametry mikroklimatu, tworząc warunki komfortowe dla użytkowników. Jednocześnie nie można stwierdzić, iż któryś z analizowanych systemów jest lepszy.

Celem przeprowadzenia analizy systemu klimatyzacji wyposażonego w nagrzewnice wtórne utworzono wykres (rys. 3). Warunki najbardziej komfortowe uzyskano w pokoju hotelowym i nauczycielskim, czyli w pomieszczeniach o najmniejszej liczbie osób. Najwyższe wartości wskaźnika PMV uzyskano w sali weselnej, gdzie była największa liczba osób oraz największa aktywność fizyczna. 
a)

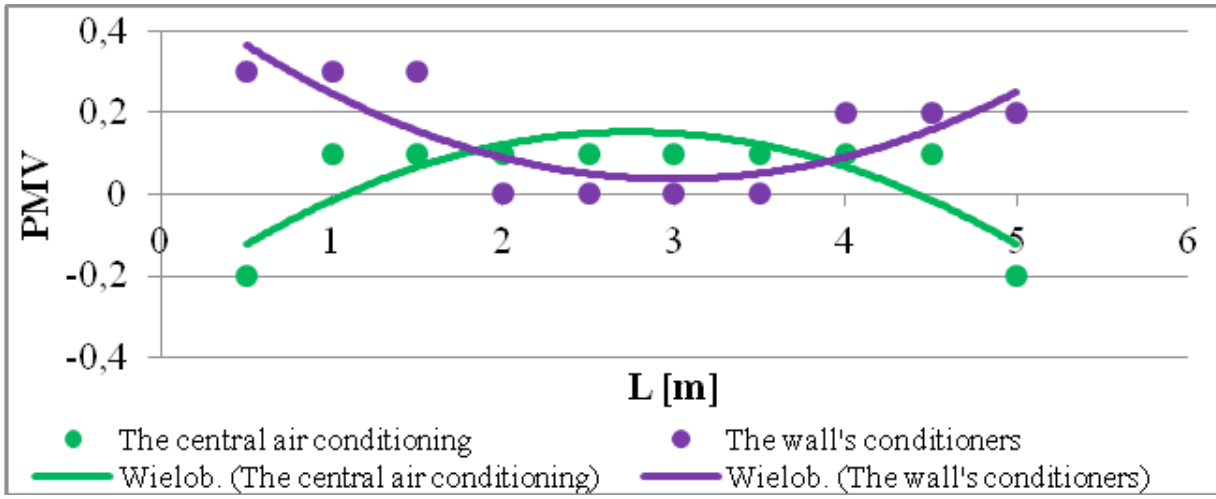

b)

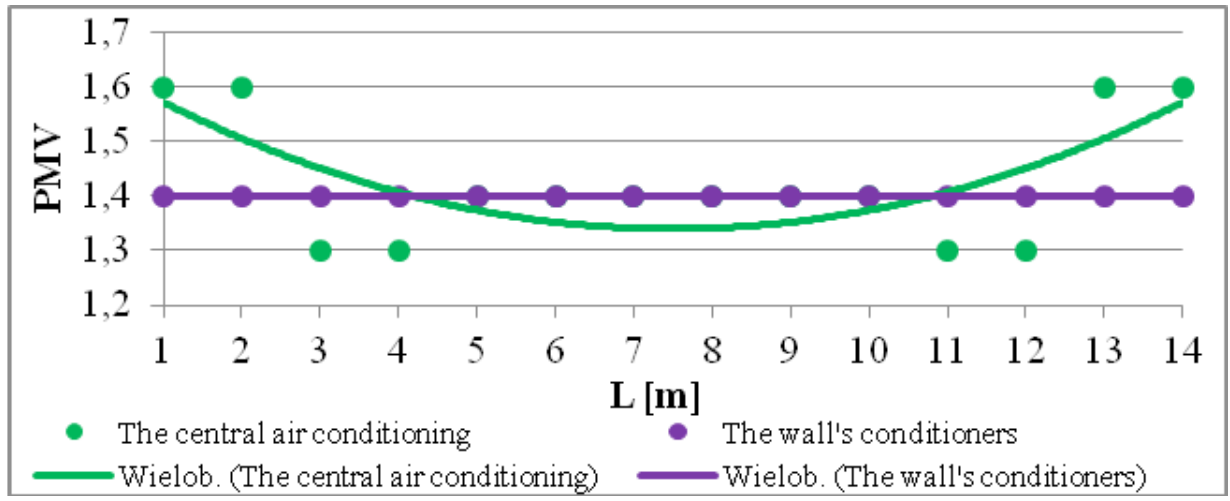

c)

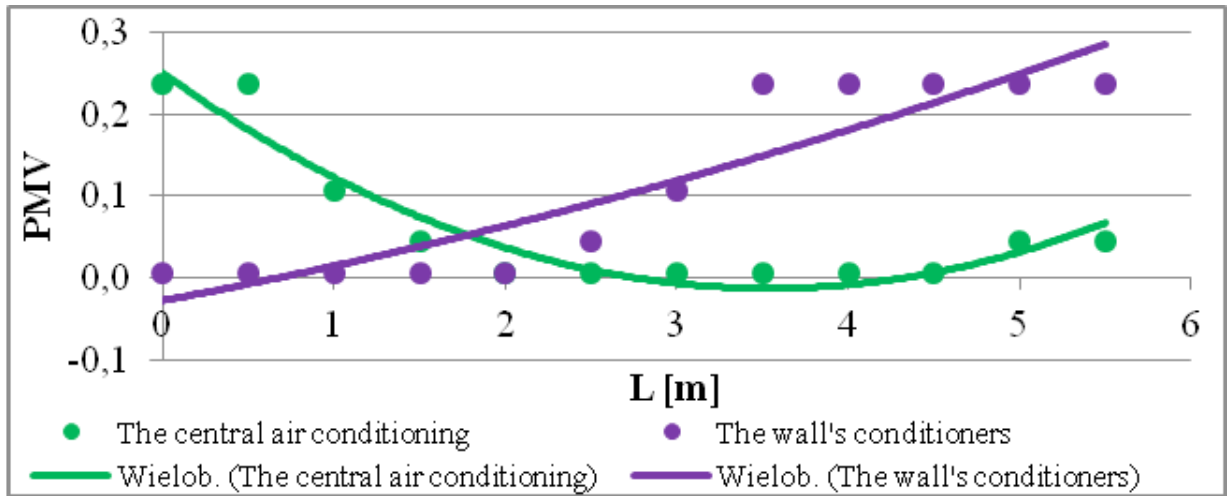

d)

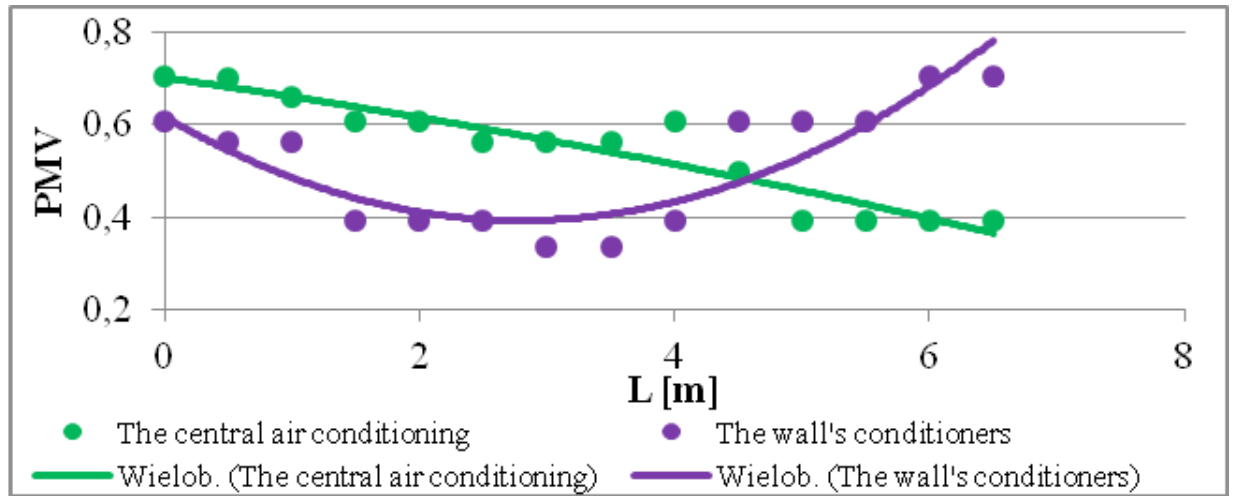

Fig. 2. The PMV value along the room depending on the type of air conditioning system: a) hotel room, b) wedding hall, c) teacher's room, d) classroom

Rys. 2. Wartość wskaźnika PMV wzdluż pomieszczenia w zależności od rodzaju instalacji klimatyzacji: a) pokój hotelowy, b) sala weselna, c) pokój nauczycielski, d) sala lekcyjna 


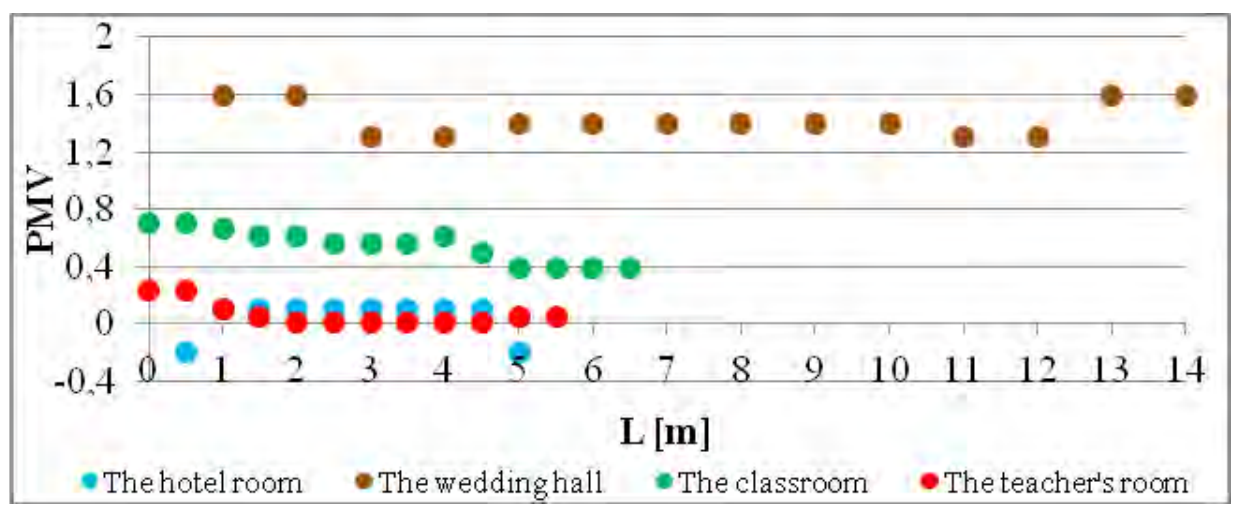

Fig. 3. The PMV value in premises with the central air conditioning system equipped with zone heaters

Rys. 3. Wartość wskaźnika PMV w pomieszczeniach klimatyzowanych przez system centralny z nagrzewnicami strefowymi

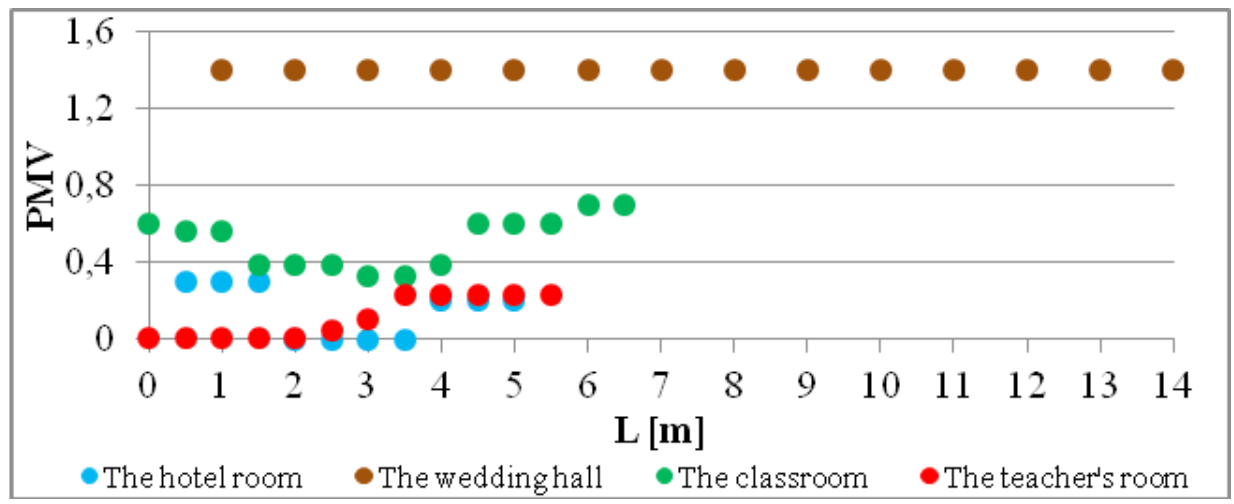

Fig. 4. The PMV value in premises with the wall's conditioners

Rys. 4. Wartość wskaźnika PMV w pomieszczeniach klimatyzowanych przez system z klimatyzatorami ściennymi

To the analyze the air conditioning system equipped with wall's conditioners the graph was created too (Fig. 4). The most comfortable conditions were obtained, as in the case of the first air conditioning system, in the hotel and teacher's room. Similarly, the highest values of the PMV factor were observed in the wedding hall.

\section{Conclusions}

The conducted analysis showed that regardless of the air conditioning system used, it is possible to obtain the comfort conditions in rooms of different use. At the same time, it can be said that it is easier to get the right parameters in the premises for rooms with fewer people and less physical activity of occupants. In the three analyzed premises, users can determine the micro-environment as slightly warm $(\mathrm{PMV}=0 \div+1)$ or slightly cool (PMV $=-1 \div 0$ ) according to [4]. In the room with the largest number of people and their greatest physical activity, thermal comfort can be defined as heat $(\mathrm{PMV}=+1 \div+2)$
Celem przeprowadzenia analizy systemu klimatyzacji wyposażonego w klimatyzatory ścienne również utworzono wykres (rys. 4). Warunki najbardziej komfortowe uzyskano, tak jak w przypadku pierwszego systemu klimatyzacji, w pokoju hotelowym i nauczycielskim. Analogicznie najwyższe wartości wskaźnika PMV zaobserwowano w sali weselnej.

\section{Wnioski}

Przeprowadzona analiza wykazała, że bez względu na zastosowany system klimatyzacji możliwe jest uzyskanie warunków komfortu cieplnego w pomieszczeniach o różnym przeznaczeniu. Jednocześnie można stwierdzić, iż w przypadku pomieszczeń o mniejszej liczbie osób i ich małej aktywności fizycznej łatwiejsze jest uzyskanie odpowiednich parametrów w pomieszczeniach. W trzech analizowanych pomieszczeniach użytkownicy mogą określić mikrośrodowisko jako lekko ciepłe $(\mathrm{PMV}=0 \div+1)$ lub lekko chłodne $(\mathrm{PMV}=-1 \div 0)$, wg [4]. W pomieszczeniu o największej liczbie osób i największej ich aktywności fizycznej komfort ciepl- 
according to [4]. Reducing the supply air temperature would increase the thermal comfort of the occupants in this room provided they maintain a high level of physical activity. However, due to the specifics of the room where some people are dancing, some sit at the table, people in the second group will evaluate the micro-environment as too cool or cool. The main conclusion of the analysis is the necessity of indepth analysis of the specifics use of the premises for the proper location of the elements of the air conditioning system and the appropriate selection of supply air parameters at the design stage. ny można określić mianem ciepło $(\mathrm{PMV}=+1 \div+2)$, wg [4]. Zmniejszenie temperatury powietrza nawiewanego spowodowałoby zwiększenie komfortu cieplnego osób przebywających w tym pomieszczeniu, pod warunkiem utrzymywania wysokiej aktywności fizycznej. Jednak z uwagi na specyfikę pomieszczenia, gdzie część osób tańczy, część siedzi przy stole, osoby $z$ drugiej grupy oceniłyby mikrośrodowisko jako zbyt chłodne lub chłodne. Zasadniczym wnioskiem z przeprowadzonych badań jest konieczność dogłębnej analizy specyfiki pomieszczenia celem odpowiedniej lokalizacji elementów końcowych instalacji klimatyzacji oraz odpowiedniego doboru parametrów powietrza nawiewanego na etapie projektowania.

\section{References}

[1] Olenets M., Piotrowski J., A model of heat and air transfer in a ventilated, rectangular space. Journal of Building Physics Vol. 40(4) (2017), pp. 334-345.

[2] Telejko M., Zender-Świercz E., An attempt to improve air quality in primary schools. $10^{\text {th }}$ International Conference: Environmental Engineering DOI: https://doi.org/10.3846/enviro.2017.051.

[2] Śmiełowska M., Marć M., Zabiegała B., Environmental Science and Pollution Research. Indoor air quality in public utility environments-a review Vol. 24, Issue 12 (2017), pp. 11166-11176.

[3] PN EN 15251 Indoor environmental input parameters for design and assessment of energy performance of buildings addressing indoor air quality, thermal environment, lighting and acoustics Parametry wejściowe środowiska wewnętrznego dotyczące projektowania i oceny charakterystyki energetycznej budynków, obejmujące jakość powietrza wewnętrznego, środowisko cieplne, oświetlenie i akustykę.

[4] PN-EN ISO 7730:2006 Ergonomics of the thermal environment. Analytical determination and interpretation of thermal comfort using calculation of the PMV and PPD indices and local thermal comfort criteria. Ergonomia Środowiska termicznego umiarkowane. Analityczne wyznaczanie i interpretacja komfortu termicznego z zastosowaniem obliczania wskaźników PMV i PPD oraz kryteriów miejscowego komfortu cieplnego.

[5] Kumar Lachireddi G.K., Muthukumar P., and Sudhakar Subudhi, Thermal comfort analysis of hostels in National Institute of Technology Calicut. Sādhana, India Vol. 42, No. 1 (2017), pp. 63-73, (DOI 10.1007/s12046-016-0572-x).

[6] Aravind Kumar A., Nagesh Babu B. and Somya S., Numerical Simulation of Thermal Comfort Performance in a Room with Different Insulating Materials using Computational Fluid Dynamics. Key Engineering Materials. Trans Tech Publications, Switzerland, Vol. 650 (2015) pp. 29-37 (DOI 10.4028/www.scientific.net/KEM.650.29).

[7] Hasan M.H., Alsaleem F., Rafaie M., Sensitivity study for the PMV thermal comfort model and the use of wearable devices biometric data for metabolic rate estimation. Building and Environment 110 (2016) pp. 173-183.

[8] PN-76/B-03420. Ventilation and air conditioning. The computational parameters of external air. Wentylacja i klimatyzacja. Parametry obliczeniowe powietrza zewnętrznego.

\section{Acknowledgments:}

This work was supported by Kielce University of Technology, Grant No. 05.0.08.00/2.01.01.01.0009 MNSP.IKFB.17.001

\section{Podziękowania:}

Praca była finansowana przez Politechnikę Świętokrzyska, grant $n$ r 05.0.08.00/2.01.01.01.0009 MNSP.IKFB.17.001 